\title{
Social Capital and Development Failure:
}

\author{
The Case Study of a Sub-surface Arsenic Removal System Site \\ in Narail, Bangladesh
}

Jay Andrew, Tahmid Huq Easher, Raisa Bashar, Nazmul Ahsan Khan

\begin{abstract}
The role of social relationships in development has important implications for contemporary development research and policy. Projects in Bangladesh fail more frequently that they should and one reason may be due to a lack of social capital among locals. The SAR (Sub-surface Arsenic Removal) system is a very viable and sustainable way to produce arsenic-free fresh water in areas like rural Bangladesh. One such SAR system is being developed in Barnal-Eliasabad in Kalia upazila of Narail district, Khulna. The aim of this study is to show that the SAR water supply system is likely going to be unsuccessful due to a lack of social capital among the villagers of Barnal-Eliasabad, Kalia upazila. The study investigated respondents' insights on the causes of failure of the community based SAR project. Qualitative research method was used to understand the research problem better. The questionnaires and interviews revealed that the locals are very dissatisfied with the SAR system, and cited some issues. However, further investigation reveals that the key reason for the failure is due to internal strife among the major families. The lack of desire to work together in spite of their awareness of the dangers of arsenic poisoning means that regardless of the all the positives, the SAR system will inevitably fail due to a lack of local support and the village will continue to use contaminated and/or limited sources of freshwater.
\end{abstract}

Keywords - social capital, development failure, Khulna

Jay Andrew

Bsc. Environmental Management

Department of Environmental Science and Management

North South University, Bangladesh

Tahmid Huq Easher

Lecturer

Department of Environmental Science and Management North South University, Bangladesh

Raisa Bashar

Lecturer

Department of Environmental Science and Management

North South University, Bangladesh

Nazmul Ahsan Khan

Professor

Department of Environmental Science and Management

North South University, Bangladesh

\section{Introduction}

In rural areas of Bangladesh, 97\% of the population relies on tube wells installed since the 1970 s to reduce diseases from ingestion of pathogen-laden surface water. Unfortunately, this has resulted in a population highly exposed to arsenic but with limited means or incentives for seeking safe water alternatives (Bala et al., 2003).

The introduction of tube wells along with the powerful involvement of the private sector in the production of the hand pumps resulted in an increased use of groundwater exaggerated the problems further (Ahmad et al., 2003). In 2014, a Subsurface Arsenic Removal (SAR) system was installed in a private house in a severely arsenic contaminated village of the Boranal - Eliasabad Union under Kalia Upazilla in Narail, Khulna (area of 350.91 sq. $\mathrm{km}$., located in between $22^{\circ} 57^{\prime}$ and $23^{\circ} 07^{\prime}$ north latitudes and in between $89^{\circ} 30^{\prime}$ and $89^{\circ} 48^{\prime}$ east longitudes) by a research group from the Department of Geology from Dhaka University.

The village's drinking water supply primarily consists of tube-wells $(96.63 \%)$, but have been found to be contaminated, with arsenic having been detected in $73.76 \%$ of shallow tube-wells of the upazila. The principle behind the SAR treatment is the injection of oxygenated water into the anoxic aquifer to create a filter made of subsurface iron oxide filter to absorb the As in the groundwater (van Halem 2010). SAR is a relatively new treatment option that can be operated with negligible waste generation and it is also costeffective i.e. it is economically viable for the rural areas of Bangladesh as it does not need any expensive filter media like the other As removal systems available in the market (Sarkar and Rahman 2001; Rott et al. 2002; Appelo and de Vet 2003; van Halem et al. 2009, 2010a, b; Sen Gupta et al. 2009; Rahman et al. 2014).

Social capital is a socioeconomic idea that refers to the connections between individuals and entities that can be economically valuable. Social networks that include people who trust and assist each other can be a powerful asset (Uslaner and Dekker 2001; Uslaner 2001; Sander 2002). 
Intuitively, then, the basic idea of "social capital" is that one's family, friends, neighbours and associates constitute an important asset; one that can be called upon in a crisis, enjoyed for its own sake, and/or leveraged for material gain (Moser 1996; Narayan and Pritchett 1997). Those communities endowed with a rich stock of social networks and civic associations will be in a stronger position to confront poverty and vulnerability, resolve disputes, and/or take advantage of new opportunities (Schafft and Brown 2000; Isham 1999).

According to social and economic scholars there is a growing evidence that social capital, can have impacts on development outcomes - growth, equity, and poverty alleviation. Associations and institutions provide an informal framework to organize information sharing, collective decision making, and coordination of activities (Woolcock, 1998; World Bank, 1997, 2000; Grootaert, 1997; Putnam 1995). Bardhan (1995) has argued that what makes this work is peer monitoring, a common set of norms and local-level sanctions. The well-known case of the Grameen Bank in Bangladesh also serves as evidence how these factors can be used by the poor to achieve individual development through small business endeavors contributing ultimately to community development (Grootaert, 1997; Krishna, 2002; Narayan, 1999; Bardhan, 1995; World Bank, 1997, 2000).

A lack of social capital in Boronal Village amongst rural community in Narail, Bangladesh impacted upon the utilization of a cost-effective and overall sustainable community based arsenic treatment unit (SAR-Subsurface Arsenic Removal) in their arsenic prone village, established there by Dhaka University which was funded by foreign donors.

\section{There is a growing evidence that social capital can have impacts on development outcomes.}

The objectives of the research were to gather information on the impacts of and reactions to the SAR system on the people during the first 6 months, to investigate and understand the development failure of SAR treatment and its correlation to social capital correlation and to find out whether these problems could be overcome through community management of the SAR system and give recommendations based on the principles of Social Impact Assessment (SIA) and Social Capital Literature

\section{Methodology and Data Collection}

Qualitative research has been found to be useful in identifying problem areas within the community organization of the Boronal Village for investigating behaviours that were considered to be sensitive and socially undesirable. The study was exploratory, because it investigated the social issues faced in Boronal SAR project, collected information from knowledgeable individuals and found a comparative analysis of similar situations through secondary data. The study investigated respondent's insight on the causes of failure of the community based SAR project. The information was obtained from participants themselves to help explore the causes of the seeming failure of the community-based SAR project in the study area and develop recommendations on how community projects can be managed in the future. This method was used to get at the inner experience of the SAR users, to determine how social issues have prevented the poor villagers from accessing safe arsenic free water. This method also has the advantage of increasing familiarity with the problem or opportunity and to clarify some key concepts connected with the research problem. The population of the study composed of consumers of the community based project established at the Boronal village, from where people from three other villages acquired arsenic safe water. The criteria employed to select the sample from the community was that they need to be direct consumer of the SAR arsenic safe water. Questionnaires were structured to ensure that each respondent was asked the same simple, clear, concise and precise questions to ensure that the responses made to those questions/issues gave answers to the study problem being explored. 45 questionnaires were designed and distributed to respondents who participated in the study. The details of the questionnaires were explained to participant before so that they understand how to approach questionnaires and what was expected from them. The questionnaire provided the opportunity to get respondent's view and experience on the topic under investigation. 


\begin{tabular}{|c|c|c|c|c|}
\hline \multicolumn{5}{|c|}{ Table 1. Demographic Data of Respondents } \\
\hline \multicolumn{5}{|c|}{ Union of Kalia Upazila } \\
\hline \multirow{2}{*}{$\begin{array}{c}\text { (SAR } \\
\text { users) } \\
\text { number } \\
\text { of } \\
\text { families }\end{array}$} & \multicolumn{4}{|c|}{$\begin{array}{l}\text { Sample Population } \\
\text { (number of people) }\end{array}$} \\
\hline & Male & Female & $\begin{array}{l}\text { Children } \\
\text { under } 15\end{array}$ & $\begin{array}{l}\text { Total Sample } \\
\text { Population } \\
\text { per village }\end{array}$ \\
\hline 28 & 30 & 34 & 52 & 116 \\
\hline 6 & 9 & 5 & 4 & 18 \\
\hline 4 & 10 & 16 & 23 & 49 \\
\hline 8 & 5 & 12 & 14 & 31 \\
\hline
\end{tabular}

Interviews were undertaken with the SAR officers to get their views and opinions on the topic under investigation. The one-on-one interviews were personal conversations in which the respondents were able talk freely about the project. A focus group was also used in this study using a similar questioning format but more than one respondent participated in the 5 interviews conducted. The interviews usually involved at least 5-6 women since they were the key people involved with the fetching of water directly from the SAR unit. This also helped in getting suggestions for the management of community projects in future.

\section{Data Analysis and}

\section{Findings}

A structured questionnaire and interviews were the instruments used for data collection in this study. Questionnaires were distributed to all participants in the study area except people who could not read or write. An interview was conducted to get information and opinions from key community members, especially with the brother of the former Ward Chairman, responsible for community development in the study area. Group discussions were conducted with the locals based on a list of topics regarding water consumption, usage patterns and community problems with water availability and access, arsenic and other health issues, or through openended questions. This was the most successful technique to deal with the respondents and almost all of the subjects were covered by this method. Informal interviewing, i.e., conversations with individuals and spontaneous discussions with groups of people (i.e. groups of people met during the visit, such as men engaged in public works, women fetching water or children playing around) often provided important insights into the local situation, the problems at stake, the basic features of social organization and potential sources of conflict. They were also essential in creating a list of grassroots people in the community that influences developmental projects in the area. For identifying key informants (i.e. knowledgeable and talkative men and women), the list was consulted during subsequent phases of the process.

Data analysis was done systematically, searching and arranging the data gathered from the interview, completed questionnaires with answers, field notes and other material that was accumulated to increase understanding of the situation in the area. Data interpretation was done in context of the situation at hand and also finding correlation from secondary data and literature. Descriptive statistics was used for analyzing data from the respondents.

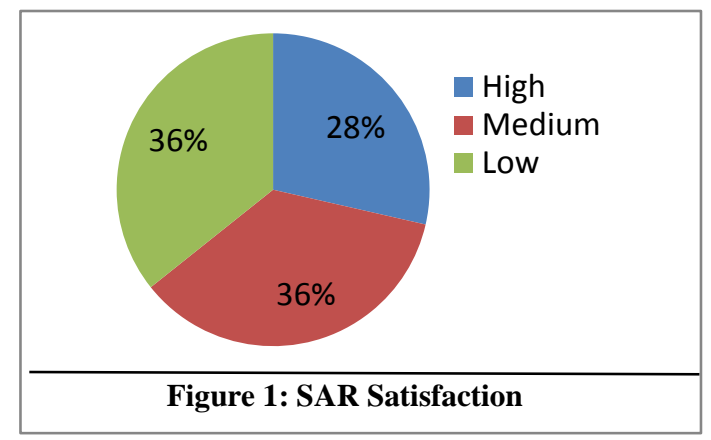

The recorded level of water consumption varied across families, averaging at around 20.19 litres daily. The variations were attributable to factors such as family size and level of household wealth, as richer households used more collected water while poorer families tended to rely more on ponds, arsenic-heavy tube-wells and the nearby river for non-consumption water usage. One major household even employed men to be their proxy in the water collection line and bring in several barrels of water, enough to last a week. During the period which the SAR system was functional, the villagers were not particularly dependent on the SAR water supply, choosing to rely on alternative sources instead. Only $31 \%$ of users within the area fully relied on the SAR water, while $39 \%$ chose to not use any at all. When questioned about their thoughts regarding the SAR's performance, even though on paper the system was functioning, producing safe, arsenic free water, the collected data showed generally negative responses. Only $28 \%$ of the respondents were truly happy with the system, and the remaining $72 \%$ split on whether they were partially or very dissatisfied, as shown in Figure 1. 
When asked about what sources they prefer to use, a massive $50 \%$ claimed to prefer the source locally referred to as the Chairman House Pump (CHP). The water source is a surface water filtration system, set up in 2014 by UNICEF collaborating with EPRC (Environment and Population Research Centre) and sponsors from The Netherlands, which takes water from the large ponds near the Chairman's house and uses sand filters to provide fresh drinking water (Figure 2).

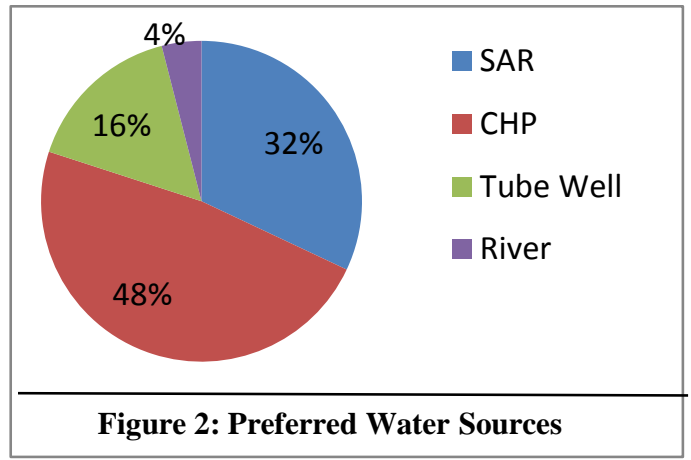

When probed further during discussions, the people who were not very satisfied said that they took issue with the high iron content in the water. While the iron-rich water was deemed safe to consume by the project supervisors, the locals refused to drink it. They claimed that it was aesthetically unpleasant and when used in cooking it left a noticeable aftertaste that made the food unappetizing. Some households (that refused to continue using the SAR) went so far as to say that even though they are well aware of the fact that the iron-rich water is safe to consume, and that their personal tube-wells are either untested or known to contain arsenic.

When asked about whether or not they would go back to using SAR supply's water once the iron contamination issues were solved, $33 \%$ of respondents said that they would abstain from returning to the SAR supply. This finding is more baffling when considering that in the dry season (i.e. when this survey was being conducted), the surface water supply was very limited, and thus the CHP was providing less and less water every day. According to the villagers, the CHP was only available once or twice a day for only a couple of hours. Most people said that they weren't getting enough water, and were using their personal tube wells and other sources, none of which were safe for consumption, be it due to a lack of testing or tests noting them as hazardous for human consumption. In spite of the locals' knowledge about the health risks, they refuse to use the SAR's water supply $-42 \%$ said that they were happy with the system, and only $33 \%$ of the respondents said that they would continue to use it, as shown in Figure 3.

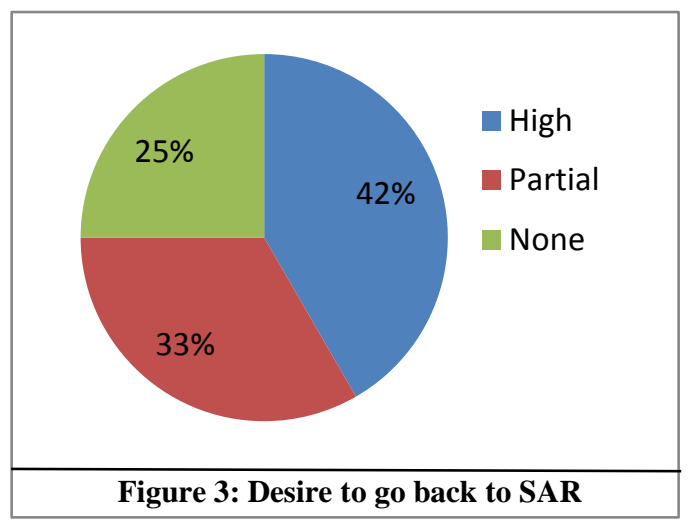

According to the project personnel, the only cost to be borne by the community would be the electricity bill from the running of the water pump - the costs of installation, maintenance and operation would be borne by the SAR project. This amount is around BDT 10 per month per household. However, in spite of the low costs, only $47 \%$ were willing to pay that cost (average monthly income among responding families ranged between BDT 7,000 and 9,000).

Through informal discussions and survey walks, it was later discovered there was a deeper, underlying reason for the disapproval towards the SAR project, and it was due to site selection. In previous similar projects, aquifer-based water supply systems were typically placed on public property, such as public schools, or important areas like mosques. However, the free-rider problem would lead to mismanagement - an issue this region was known for, as the CHP project was also being mismanaged with little to no maintenance being done and people going back on their word in the past regarding payment (according to a member of a former Chairman's household). To avoid that issue, the SAR project was put on private property of a rich family, with the idea being that if the community does not collect payments fast enough, the family can intervene and pay off the fees on their own while waiting for the collections to be made. However, they did not take into account the social issues that plague Barnal-Eliasabad. There are deeper issues at play in regards to the social unrest among the families. There has been a long history of disagreements and aggression between the major families as well as within the families as well, resulting in a lack of trust and co-operation, in spite of the long-term health risks involved. Recent gains in wealth and improvement of living conditions have bred contempt in an already volatile community that are reportedly known for going back on their word. These types of underlying social issues hamper the chances of a stable Community Based Organization to be formed. Families that are at odds went so far as to 
ask the project to make multiple SAR sites preferably one at a local public school a few blocks away rather than make amends and collect water from the existing site. Also, many see the idea of having to go to someone's house to get water as a social faux-pas, further limiting their desirability of using the system.

\section{Iv. Conclusion}

The questionnaires and interviews revealed that the locals are very much dissatisfied with the SAR, and citing some issues, such as high iron content.

However, further investigation reveals that the negativity towards the project comes from the Sheikh family, who take offence to have to go onto the private property of the Molla family, who they see as local rivals. Furthermore, the Molla family themselves also show desire to cut them out completely, as they have the capacity to provide the system's running costs on their own. With the two largest local families at odds over the system, the local community will likely never be able to truly work together to use and maintain the system. Several households already showing they would rather drink from arsenic-contaminated tubewells on their own properties.

The lack of desire to work together in spite of their awareness of the dangers of arsenic poisoning means that in spite of the all the positives, the SAR will inevitably fail due to a lack of local support and the village will continue to use contaminated and/or limited sources of freshwater. At best, it will serve as a system providing water to only the Mollabari and those families that are on good terms with them, while the rest of the village suffers.

\section{v. Way Forward}

Development projects are set up using donor funds, but require the willpower of the locals to truly become sustainable. While setting up systems in developing areas, further research should be conducted into the history of the area, particularly in terms of previous projects and local cohesion. These data are not that difficult to collect, and had they been collected for this particular SAR site, some warning signs could have been identified. Another possible way is to set up Community Based Organizations (CBOs) for smaller projects to gauge the level of social capital so that important development projects down the line are successful and sustainable. According to organizations such as the Flood Hazard Research Centre (FHRC), creating CBOs and giving them tasks to prove their functionality and existence over a period of several years is a great barometer for measuring social capital, and can help identify key groups that will receive the most positive impact from development related investments.

\section{References}

Ahmad, J., Goldar, B.N., Misra, S., and Jakariya, M. (2003) Willingness to Pay for Arsenic-Free, Safe Drinking Water in Bangladesh. The World Bank and Bangladesh Rural Advancement Committee

Appelo, C.A.J., de Vet, W.W.J.M. (2003). Arsenic in Groundwater: Geochemistry and Occurrence pp. 381401. Springer US. ISBN: 978-0-306-47956-4

Bala, P., Torafder, P., Azad, A. K., Anwar, A. H. M. N. (2012). Environment and public health hazard of arsenic and their remedies-A review. Bangladesh Res. Pub. J. 7(1): 69-79. Retrieved from

http://www.bdresearchpublications.com/admin/journal/u pload/09317/09317.pdf

Bardhan, P. K. (1995). Research on poverty and development twenty years after redistribution with growth. In $O P S$ Document Reproduction Series (No. 64). World Bank.

Grootaert, G. (1997). The Determinants of Poverty in Côte d'Ivoire in the 1980s. The Journal of Africal Economics (1997) 6 (2): 169-196.

Isham, J., Kähkönen, S. (1999) What Determines The Effectiveness Of Community-Based Water Projects? Evidence from Central Java, Indonesia on Demand Responsiveness, Service Rules, and Social Capital. The World Bank. Retrieved from http://siteresources.worldbank.org/INTSOCIALCAPIT AL/Resources/Social-Capital-Initiative-Working-PaperSeries/SCI-WPS-14.pdf

Krishna, A. (2002). Active social capital: Tracing the roots of development and democracy. Columbia University Press.

Moser, S. (1996). Science and social values: presenting archaeological findings in museum displays.

Narayan, D., \& Pritchett, L. (1999). Cents and sociability: Household income and social capital in rural Tanzania. Economic development and cultural change, 47(4), 871-897.

Putnam, R. D. (1995). Bowling alone: America's declining social capital. Journal of democracy, 6(1), 65-78.

Rahman S., Kim, K., S Saha, S. K., Swaraz A.M., Paul, D. K (2014). Review of remediation techniques for arsenic (As) contamination: A novel approach utilizing bioorganisms.

Rott, U., Meyer, C., Friedle M. (January 2002). Residue-free removal of arsenic, iron, manganese and ammonia from groundwater. Water Science and Technology Volume 2 Issue 1 pp 17-24. IWA Publishing

Sander, T.H. (2002) Social Capital and New Urbanism: Leading a Civic Horse to Water? National Civic Review, Vol. 91, No. 3, Fall 2002. Wiley Periodicals, Inc.

Sarkar, A.R., Rahman, O.T. (2001) In-Situ Removal of Arsenic - Experiences of DPHE-Danida Pilot Project. Retrieved from http://archive.unu.edu/env/Arsenic/Sarkar.pdf 
Proc. of The Seventh Intl. Conf. On Advances In Economics, Social Science and Human Behaviour Study - ESSHBS 2017 Copyright (C) Institute of Research Engineers and Doctors, USA .All rights reserved.

ISBN: 978-1-63248-137-5 doi: 10.15224/ 978-1-63248-137-5-32

Schafft, K.A., Brown, D.L. (2000) Social Capital and Grassroots Development: The Case of Roma Self-Governance in Hungary. Social Problems Vol. 47 Issue 2 (1 May 2000). Oxford Academic.

Sengupta, M.K., Dasgupta, P.K. (2009). An Automated Hydride Generation Interface to ICPMS for Measuring Total Arsenic in Environmental Samples. Analytical Chemistry, Vol. 81, No. 23, December 1, 2009.

Uslaner, E.M., Dekker, P. (2001) The Social of Social Capital. Social capital and participation in everyday life, pp.176-187. Routledge. ISBN: 9780415232739

Uslaner, E.M. (2001). The Internet and Social Capital. Retrieved from

https://www.researchgate.net/profile/Eric_Uslaner/publi cation/220427583_Trust_online_trust_offline/links/57a0 a95108aeef35741b3c1b.pdf

van Halem D., S.G.J. Heijman, G.L. Amy, and J.C. van Dijk (2009) Subsurface arsenic removal for small-scale application in developing countries, Desalination 248(12): 241-248.

van Halem D., S. Olivero, W.W.J.M. de Vet, J.Q.J.C. Verberk, G.L. Amy and J.C. van Dijk (2010) Subsurface iron and arsenic removal for shallow tube well drinking water supply in rural Bangladesh, Water Research 44: 57615769.

van Halem D., R. Johnston, I.M. Huq, S.K. Ghosh, J.Q.J.C Verberk, J.C. van Dijk and G.L. Amy (2010) Subsurface iron and arsenic removal: low-cost technology for communitybased drinking water supply in Bangladesh. Water Science and Technology: Water Supply 62(11): 2702-2709.

Woolcock, M. (1998). Social capital and economic development: Toward a theoretical synthesis and policy framework. Theory and society, 27(2), 151-208.

World Bank (1997). World Development Report 1997 : The State in a Changing World. New York: Oxford University Press. () World Bank. Retrieved from: https://openknowledge.worldbank.org/handle/10986/598 0 License: CC BY 3.0 IGO

World Bank (2000) Attacking Poverty: Opportunity, Empowerment, and Security. (2000). World Development Report 2000/2001, 1-12. doi:10.1596/0195211294_overview

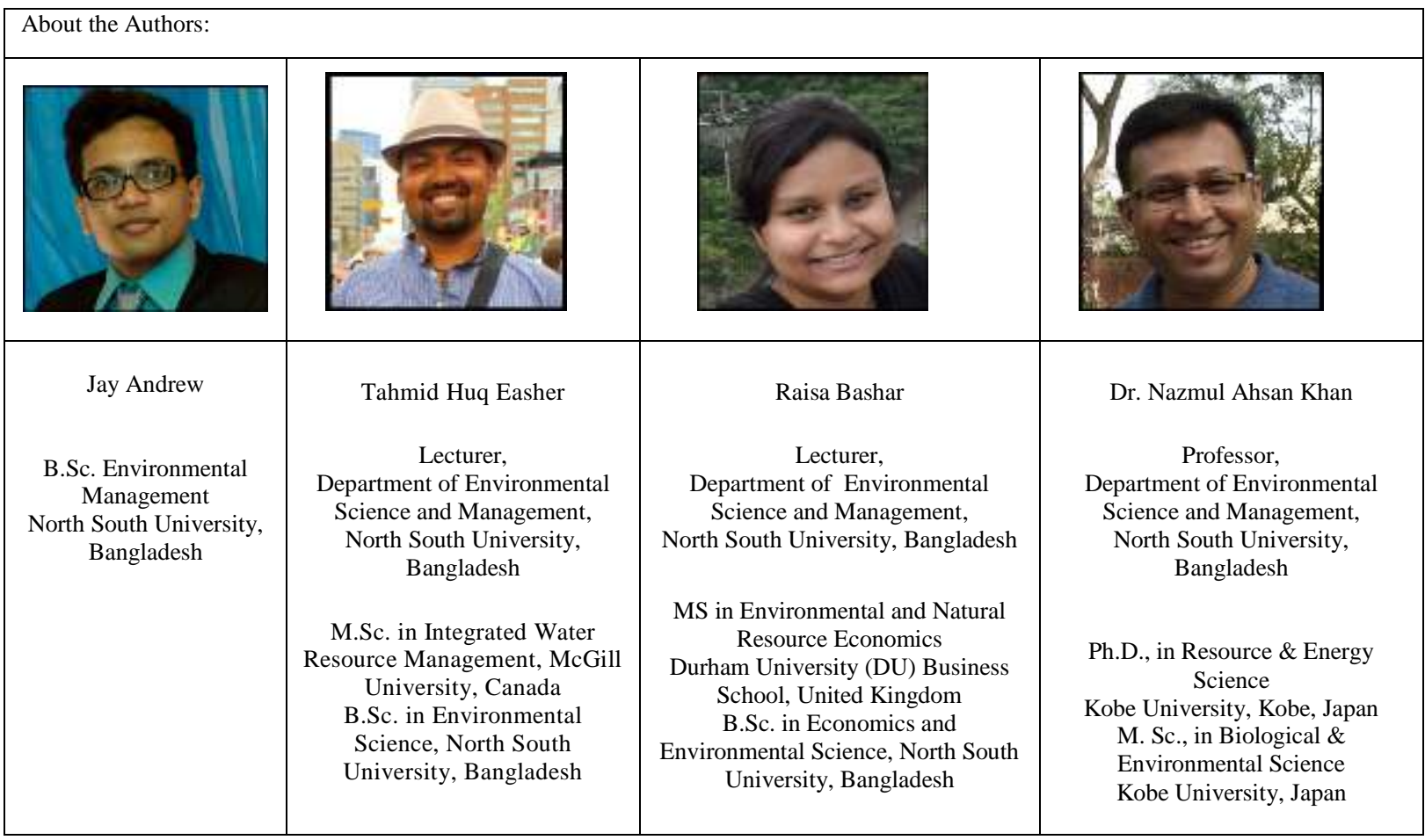

